\title{
Mikroekonomska analiza utjecaja emocija liječnika i pacijenata na ishode zdravstvene zaštite
}

\section{Microeconomic analysis of the impact of physicians' and patients' emotions on health care outcomes}

\section{Sažetak}

Cilj ovog rada je istražiti kako emocije koje doživljavaju liječnici i pacijenti u međusobnoj interakciji dugoročno utječu na promjene njihovog ponašanja i ishode zdravstvene zaštite. Liječnici i pacijenti uče iz prethodnih iskustava i njihovo ponašanje evoluira tako da učestalije izabiru strategije kojima ostvaruju veću očekivanu psihološku korisnost od prosječne. U analizi ovog problema koji se promatra iz dinamičke perspektive koriste se složeni matematički alati evolucijske teorije igara i replikatorne dinamike koji uključuju detaljno istraživanje ponašanja sustava diferencijalnih jednadžbi. Znanstveni doprinos ovog rada očituje se u analizi različitih scenarija utjecaja frustracija, žaljenja i krivnje na dugoročno ponašanje liječnika i pacijenata i pokazuje kako ponašanje sustava značajno ovisi o opsegu i snazi emocija koje liječnik i pacijent doživljavaju. Na taj način se omogućava nalaženje mjera kojima bi se zdravstveni sustav pokrenuo u smjeru društveno poželjnog stanja populacije liječnika koji žele liječiti pacijente i populacije pacijenata koji vjeruju liječnicima čime se ostvaruje i praktična vrijednost ovog rada. S obzirom da širi skup emocija koje doživljavaju liječnik i pacijent u međusobnoj interakciji značajno utječe na moguće ponašanje sustava izvedene rezultate u ovom radu valja sagledati kritički.

Ključne riječi: očekivana psihološka korisnost, evolucijska teorija igara, replikatorna dinamika, anticipirane emocije, ishodi zdravstvene zaštite

JEL klasifikacija: $\mathrm{C73}, \mathrm{D} 00,115$

\section{Abstract}

The aim of this paper is to investigate how the emotions experienced by physicians and patients in their interaction with each other in the long-run affect changes in their behavior and health care outcomes. Physicians and patients learn from previous experiences and their behavior evolves so that they more often choose strategies that achieve higher-than-average psychological utility. In the analysis of this problem from a dynamic perspective complex mathematical tools of evolutionary game theory and replicator dynamics are used, which include a detailed study of the behavior of systems of differential equations. The scientific contribution of this paper is reflected in the analysis of different scenarios of the impact of frustrations, regrets and guilt on the long-term behavior of physicians and patients and shows that system behavior depends significantly on the extent and strength of emotions experienced by physicians and patients. In this way, it is possible to find effective policy measures. Given that the wider set of emotions experienced by the doctor and the patient in interaction with

\section{Ilko Vrankić}

Prof.dr.sc.

Ekonomski fakultet Sveučilišta u Zagrebu

E-mail: ivrankic@efzg.hr

\section{Ilko Vrankić}

Prof.

Faculty of Economics and Business, University of Zagreb

E-mail: ivrankic@efzg.hr 
Vrankić, I.

Mikroekonomska analiza utjecaja emocija liječnika i pacijenata na ishode zdravstvene zaštite

each other significantly affects the possible behavior of the system, the results derived in this paper should be interpreted critically.

Keywords: psychological expected utility, evolutionary game theory, replicator dynamics, anticipatory feelings, health care outcomes

JEL classification: $\mathrm{C73,D00,115}$

\section{Uvod}

Unutar zdravstvenog sustava osobitu važnost ima međusobna interakcija liječnika i pacijenta. U toj interakciji liječnik i pacijent mogu doživljavati različite emocije. Emocije koje doživljavaju značajno utječu na njihovu očekivanu psihološku korisnost. U medicini orijentiranoj na pacijenta ishodi zdravstvene zaštite uključuju zdravstvene ishode i psihološke doživljaje pacijenta. Očekivana psihološka korisnost je generalizacija koncepta von Neumann-Morgensternove funkcije korisnosti koja anticipira buduće osjećaje (Caplin i Leahy, 2001.). Odnos liječnika i pacijenta je složen i rezultat zdravstvene zaštite ovisi o njihovim odlukama. Ishodi zdravstvene zaštite imaju važne implikacije na zdravlje pojedinaca i njihovo blagostanje. Važna dimenzija učinkovitih zdravstvenih sustava je dostupnost zdravstvenih usluga. Značajan broj pacijenata nije zadovoljan dostupnošću zdravstvenih usluga zbog financijskih razloga, geografskog položaja ili predugog čekanja ili smatraju da dobivena zdravstvena usluga nije adekvatna njihovom zdravstvenom stanju. U tom slučaju zdravstveni sustav nije učinkovit i neprikladna zdravstvena skrb ima višestruke negativne ekonomske posljedice. Pojedinci koji ne dobivaju prikladnu zdravstvenu skrb dulje vremena provode na bolovanju i manje doprinose gospodarskoj aktivnosti. Na njihovo blagostanje negativno utječe njihovo fizičko i psihičko stanje, izdvajanja za javnu zdravstvenu skrb koju ne dobivaju i značajno povećani troškovi privatnog liječenja na koje su prinuđeni. Na taj način se dovodi u pitanje povjerenje u sustav zdravstvene zaštite i narušava socijalna kohezija.

Cilj ovog rada je istražiti kako emocije koje doživljavaju liječnik i pacijent u međusobnoj interakciji utječu na realizaciju prikladne zdravstvene zaštite i dugoročnu učinkovitost zdravstvenog sustava. Odnos liječnika i pacijenta modelira kao simultana igra u kojoj liječnik i pacijent imaju na raspolaganju dvije strategije. Liječnik odlučuje o tome želi li liječiti pacijenta ili to ne želi činiti, a pacijent odlučuje o tome hoće li vjerovati liječniku ili neće. Isplate liječnika i pacijenta ovise 0 zdravstvenim ishodima i anticipiranim emocijama. Kada pacijent ne vjeruje liječniku i ne prihvaća preporučenu terapiju liječnik osjeća frustraciju jer ne može pomoći pacijentu, a pacijent kasnije osjeća žaljenje zbog toga što nije vjerovao liječniku i liječio se. Liječnik koji ne propisuje prikladni terapiju pacijentu može osjećati krivnju, a pacijent koji vjeruje takvom liječniku i ne liječi se zbog toga žali. Ako pacijent ne vjeruje liječniku koji ga ne želi liječiti može prikladnu zdravstvenu zaštitu dobiti privatno, ali tada osjeća frustraciju zbog neprikladne zdravstvene zaštite i dodatnih troškova kojima je izložen. Na osnovi racionalnost liječnika i pacijenta u okviru njihovih strateških promišljanja opisuju se krivulje reakcije i Nashove ravnoteže. Analiziraju se različiti scenariji, ovisno o emocijama koje liječnik i pacijent doživljavaju. U situacijama u kojima postoji više Nashovih ravnoteža postavlja se pitanje koje se od njih mogu smatrati dugoročnim rezultatom igre. Do odgovora na ovo pitanje dolazi se primjenom evolucijske teorije igara i replikatorne dinamike. Osnovna ideja je postupna prilagodba zbog koje liječnik i pacijent učestalije biraju strategije koje im daju veću očekivanu korisnost od ukupne ili prosječne očekivane korisnost. Sustav diferencijalnih jednadžbi opisuje ponašanje liječnika i pacijenta u vremenu pri čemu se stabilnost stacionarnih točki određuje na osnovi predznaka svojstvenih vrijednosti Jacobijeve matrice. Ponašanje sustava opisuju vektorsko polje i fazni dijagram koji se u jednom slučaju konstruira metodom prvog integrala jer predznak svojstvenih vrijednosti stacionarnih točaka ne omogućava jasnu predodžbu o izgledu orbita. Na osnovi faznog dijagrama daje se odgovor na pitanje dugoročne učinkovitosti zdravstvenog sustava koja ovisi 0 
njegovom početnom stanju.

Znanstveni doprinos ovog rada očituje se u analizi utjecaja frustracija, žaljenja i krivnje na dugoročno ponašanje liječnika i pacijenata primjenom složenih alata evolucijske teorije igara, replikatorne dinamike i analize stabilnosti pri čemu se pokazuje kako ponašanje sustava značajno ovisi o snazi emocija koje liječnik i pacijent doživljavaju. Komparativno statičkom analizom i usporedbom različitih scenarija omogućava se nalaženje mjera kojima bi se ostvarilo društveno poželjno stanje populacije liječnika koji žele liječiti pacijente i populacije pacijenata koji vjeruju liječnicima čime se ostvaruje i praktična vrijednost ovog rada.

Nakon uvoda daje se pregled literature i pokazuje znanstvena utemeljenost isplata liječnika i pacijenata na kojima se zasniva dinamička analiza u ovom radu. U poglavlju o metodologiji opisuju se osnovni koncepti evolucijske teorije igara, replikatorne dinamike i ponašanja sustava diferencijalnih jednadžbi. U središnjem poglavlju analiziraju se model sa frustracijom i žaljenjem, te prošireni model sa frustracijom, žaljenjem i krivnjom u okviru kojeg se posebno analiziraju tri slučaja u ovisnosti o tome je li dominantan osjećaj frustracije ili krivnje liječnika. Članak završava zaključkom u kojem se uspoređuju izvedeni rezultati i predlažu mjere za poboljšanje kvalitete zdravstvenog sustava.

\section{Pregled literature}

Učinkovitost pružanja zdravstvenih usluga značajno ovisi o međusobnoj interakciji liječnika i pacijenata.S obzirom da ishodi zdravstvene zaštite ovise o odlukama različitih subjekata prirodan okvir za analizu je teorija igara. Tradicionalna teorija igara proučava statičke i dinamičke igre s potpunim i nepotpunim informacijama i ima opsežnu primjenu u ekonomiji (Gibbons, 1992.). Ekonomska literatura često zanemaruje da na subjekte utječu emocije koje doživljavaju međusobnoj interakciji i modeliranje strateških odgovora na anticipirane emocije opisuje Kőszegi (2006.). Anticipirane emocije zbog budućih neizvjesnih događaja utječu na očekivanu psihološku korisnost (Caplin i Leahy, 2001.). Glycopantis i Stavropoulou (2011., 2018.) odnos liječnika i pacijenta analiziraju kao principal agent problem. U njihovim radovima liječnik odlučuje o tome koliko detaljno izvijestiti pacijenta o budućem zdravstvenom stanju pri čemu se pacijenti međusobno mogu razlikovati s obzirom na preferencije prema informacijama. Pacijenti nakon što dobiju informacije od liječnika odlučuju o tome hoće li prihvatiti preporučenu terapiju. $\mathrm{Na}$ očekivanu psihološku korisnost pacijenta utječe percepcija budućeg zdravstvenog stanja i emocije koje doživljava u komunikaciji s liječnikom. Tako pacijenti koji su skloni informacijama osjećaju ljutnju i zabrinutost da bi im terapija mogla naškoditi kada od liječnika ne dobiju detaljne informacije o svom zdravstvenom stanju. $\mathrm{Na}$ liječnika koji je empatičan prema pacijentu utječe buduće zdravstveno stanje pacijenta, emocije i trud koji ulaže u komunikaciju s pacijentom. Analiza modela s asimetričnim informacijama zasniva se na konceptu savršene Bayesove ravnoteže i vjerovanju o tipu pacijenta s obzirom na sklonost prema informacijama. Koncept savršene Bayesove ravnoteže koristi se za dinamičke igre sa nesavršenim ili nepotpunim informacijama. Tipove različitih dinamičkih igara opisuju Haurie i suradnici (2012.).

Djulbegovic i suradnici (2015.) opisuju statičku igru liječnika i pacijenta u kojoj liječniku nisu na raspolaganju daljnji dijagnostički pregledi i postoji neizvjesnost o tome je li pacijentu potrebna terapija.Zdravstveni ishodi ovise o tome preporuča li liječnik terapiju, vjeruje li pacijent liječniku i 0 tome je li pacijent zdrav ili bolestan. $U$ medicini orijentiranoj na djelovanje više se vrednuje davanje terapije pacijentu kojem je terapija potrebna nego izostavljanje terapije zdravoj osobi. S obzirom na načelo da medicinski tretman ne smije naškoditi više se vrednuje izostavljanje terapije zdravoj osobi nego davanje nepotrebne i potencijalno štetne terapije zdravoj osobi. Najlošiji ishod je izostavljanje terapije pacijentu kojemu je terapija potrebna. U ovom modelu definiraju se žaljenje, krivnja i frustracija i opisuje kako utječu na korisnost liječnika i pacijenta. Prednost ove analize jest osebujnost u pogledu izbora varijabli koje utječu na odluke liječnika i pacijenta, a nedostatak njezina statička narav. Prirodno je pretpostaviti da ljudi vremenom uče i prilagođavaju svoje ponašanje. Tako liječnici i pacijenti mogu mijenjati svoje ponašanje i učestalije birati strategije koje im daju veću očekivanu korisnost od ukupne ili prosječne
Vrankić, I.

Mikroekonomska analiza utjecaja emocija liječnika i pacijenata na ishode zdravstvene zaštite 
Vrankić, I.

Mikroekonomska analiza utjecaja emocija liječnika i pacijenata na ishode zdravstvene zaštite očekivane korisnosti. Koncept prilagodbe potječe iz biologije i na njemu se zasniva evolucijska teorija igara. U okviru evolucijske teorije igara definira se pojam evolucijski stabilnih strategija (Smith, 1982.). Evolucijski stabilne strategije populacije ne može ugroziti pojava malog broja mutanata ili subjekata koji upotrebljavaju druge strategije ponašanja. Na koji način populacija mijenja svoja obilježja opisuje replikatorna dinamika i koji su odnosi između Nashove ravnoteže, evolucijski stabilnih strategija i stabilnosti stacionarnih točaka opisuje Barron (2013.). Evolucijsku teoriju igara i replikatornu dinamiku detaljno objašnjavaju Roca i suradnici (2009.). Asimetrične evolucijske igre u kojima sudjeluju dvije populacije analiziraju Schecter i Gintis (2016.). Taj okvir je prikladan za analizu populacije liječnika i populacije pacijenata. Stabilnosti stacionarnih točaka može se odrediti na osnovi predznaka svojstvenih vrijednosti Jacobijeve matrice (Simon i Blume, 1994.). Evolucijske modele u ekonomiji i pravu opisuje Hirshleifer (2001.) i njegov rad predstavlja sistematičan pristup ekonomskoj analizi emocija.

U ovom radu korisnosti liječnika i pacijenata se opisuju u skladu s relevantnom znanstvenom literaturom i primjenjuje replikatorna dinamika za analizu populacije liječnika i pacijenata. Analizira se kako frustracija, žaljenje i krivnja utječu na dugoročno ponašanje liječnika i pacijenata i pokazuje kako ponašanje sustava značajno ovisi o emocijama koje pacijent i liječnik doživljavaju po čemu se ovaj rad razlikuje od drugih radova u ovom području.

\section{Metodologija}

Cilj ovog rada je istražiti kako frustracija, žaljenje i krivnja koje doživljavaju liječnik i pacijent u međusobnoj interakciji utječu na realizaciju prikladne zdravstvene zaštite i dugoročnu učinkovitost zdravstvenog sustava. Društveno poželjno stanjejepopulacijaliječnika kojiželeliječiti i pacijenata koji vjeruju liječnicima i u ovom radu se istražuju koje mjere mogu potaknuti promjene u sustavu zdravstvene zaštite koje dugoročno vode $u$ tom smjeru. $S$ obzirom na dinamičku narav problema u kojem liječnici i pacijenti uče iz prethodnih iskustava i njihovo ponašanje evoluira prirodan okvir za analizu je evolucijska teorija igara i replikatorna dinamika. Isplate liječnicima i pacijentima $s$ obzirom na strategije koje izabiru ovise 0 zdravstvenim ishodima i emocijama koje proživljavaju. Zdravstveni ishodi se vrednuju u skladu sa filozofijom suvremene medicine koja je usmjerena na djelovanje i načelo "prvo nemojte nauditi" (Djulbegovic i suradnici, 2015.). Utjecaj emocija na ponašanje subjekata se u ekonomskoj literaturi često zanemaruje. Anticipirane emocije utječu na očekivanu psihološku korisnost (Caplin i Leahy, 2001.) i subjekti na njih strateški odgovaraju (Kőszegi, 2006.). U ovom radu se uzimaju u obzir utjecaji frustracije, žaljenja i krivnje na očekivanu psihološku korisnost liječnika i pacijenata, izvode krivulje reakcije i nalazi jedna ili više Nashovih ravnoteža ovisno o scenariju koji se razmatra. Kako bi se utvrdilo koja se Nashova ravnoteža može smatrati rezultatom igre formulira se sustav diferencijalnih jednadžbi koji opisuje promjenu ponašanja liječnika i pacijenata u vremenu. Osnovna ideja replikatorne dinamike jest da liječnici i pacijenti učestalije biraju strategije koje im daju veću očekivanu korisnost od prosječne očekivane korisnosti. S obzirom na složenost sustava diferencijalnih jednadžbi koji opisuje promjene u populaciji liječnika i populaciji pacijenata koristi se vektorsko polje za konstrukciju faznog dijagrama kada je poznata stabilnost stacionarnih točaka. Stabilnost stacionarnih točaka utvrđuje se na osnovi predznaka svojstvenih vrijednosti Jacobijeve matrice. Kada na ovaj način nije moguće utvrditi stabilnost stacionarnih točaka za konstrukciju faznog dijagrama koristi se metoda prvog integrala. Osnovna ideja ove metode jest da se pronađe funkcija za koju su orbite dijelovi njezinih nivo linija. Upotrebom ovih složenih alata pokazuje se kako opseg emocija koje doživljavaju liječnik i pacijent i snaga tih emocija značajno utječu na dugoročno ponašanje sustava. Na ovaj način korištenjem komparativno statičke analize i usporedbom različitih scenarija mogu se izvesti mjere zdravstvene politike koje vode u smjeru društveno poželjnog stanja.

\section{Model i rezultati}

\subsection{Model s frustracijom i žaljenjem}

Pretpostavlja se da liječnik i pacijent sudjeluju u statičkoj igri s potpunim informacijama. Liječnik 


\section{Pacijent $\begin{array}{cc}\mathrm{V} & \mathrm{NV} \\ \text { Liječnik } \mathrm{L}\left[\begin{array}{cc}1,1 & -f_{d},-r \\ 0,-r & 0,1-f_{p}\end{array}\right]\end{array}$}

Vrankić, I.

Mikroekonomska analiza utjecaja emocija liječnika i pacijenata na ishode zdravstvene zaštite

Izvor: izrada autora.

ima na raspolaganju dvije strategije. Strategija L podrazumijeva da liječnik posveti vrijeme pacijentu, propiše mu prikladnu terapiju i želi liječiti pacijenta. Strategija NL ima suprotno značenje, liječnik ne posvećuje vrijeme pacijentu nego ga zanemaruje, ne daje mu terapiju i ne želi ga liječiti ili ga ne može liječiti zbog preopterećenosti ili nedostatka vremena i medicinskih sredstava. Pacijent također ima na raspolaganju dvije strategije. Strategija V opisuje pacijenta koji vjeruje liječniku. To znači da ako mu liječnik propiše terapiju pacijent je dosljedno provodi i liječi se, a ako mu liječnik ne propiše terapiju pacijent se ne liječi. Strategija NV opisuje pacijenta koji ne vjeruje liječniku. Ako mu liječnik propiše terapiju pacijent se ne pridržava uputa liječnika, ne uzima terapiju i ne liječi se, a ako mu liječnik ne propiše terapiju pacijent traži drugo mišljenje, dobiva terapiju od drugog liječnika i liječi se. Igra sa isplatama liječnika i pacijenta redom prikazana je na Slici 1.

Vrednovanje pojedinih ishoda zasniva se na pretpostavkama koje navode Djulbegovic i suradnici (2015.). Više se vrednuje ishod koji podrazumijeva liječenje bolesnog pacijenta nego ishod kada se ne daju lijekovi zdravoj osobi. Ova pretpostavka je u skladu s filozofijom suvremene medicine koja prednost daje djelovanju u odnosu na ne djelovanje. Ishod koji podrazumijeva da se ne daju lijekovi zdravoj osobi se više vrednuje od ishoda kada se daju lijekovi zdravoj osobi u skladu s načelom da se ne nanosi šteta. Ishod koji podrazumijeva da se daju lijekovi zdravoj osobi se više vrednuje od najnepovoljnijeg ishoda kada se propusti dati terapiju bolesnom pacijentu. U ovom modelu se pretpostavlja da pacijent treba terapiju i najpovoljnijem zdravstvenom ishodu liječenja bolesnog pacijenta se pridružuje normirana vrijednost 1, dok se najnepovoljnijem zdravstvenom ishodu ne liječenja bolesnog pacijenta pridružuje normirana vrijednost 0 . Prema tome ako liječnik propiše odgovarajuću terapiju pacijentu koji mu vjeruje isplata svakog od njih je 1 jer liječnik osjeća profesionalno zadovoljstvo i pacijent se liječi.

Na korisnost liječnika i pacijenta osim zdravstvenih ishoda utječu i moguće negativne emocije koje proživljavaju u međusobnoj interakciji. Ako liječnik propiše terapiju pacijentu koji mu ne vjeruje pacijent odbija terapiju i ne liječi se. Liječnik nema osjećaj profesionalnog zadovoljstva nego je frustriran što ne može pomoći takvom pacijentu. Frustracija koja umanjuje korisnost liječnika se definira kao frakcija razlike između vrijednosti najpovoljnijeg i stvarnog ishoda, pa je isplata liječnika $0-f_{d}(1-0)=-f_{d}$, gdje je $f_{d} \in\langle 0,1]$ koeficijent frustracije liječnika. Pacijent se ne liječi i zbog toga kasnije osjeća žaljenje koje umanjuje korisnost pacijenta za frakciju razlike između vrijednosti najpovoljnijeg i stvarnog ishoda, pa je isplata pacijenta $0-r(1-0)=-r$, gdje je $\overline{r \in\langle 0,1]}$ koeficijent žaljenja pacijenta.

Ako liječnik ne želi liječiti pacijenta i ne preporuča mu terapiju isplata liječnika je 0 jer nema profesionalnog zadovoljstva. Ako pacijent vjeruje takvom liječniku ne liječi se i kasnije osjeća žaljenje, pa je ponovno isplata pacijenta $-r$.

$U$ četvrtoj situaciji liječnik ne želi liječiti pacijenta i ne preporuča mu terapiju. Pacijent mu ne vjeruje nego traži drugo mišljenje, dobiva terapiju od drugog liječnika i liječi se. lako je zdravstveni 
Vrankić, I.

Mikroekonomska analiza utjecaja emocija liječnika i pacijenata na ishode zdravstvene zaštite ishod za njega povoljniji nego da se ne liječi, u ovom procesu pacijent osjeća frustraciju koja umanjuje njegovu korisnost za frakciju razlike između vrijednosti najpovoljnijeg ishoda i vrijednosti potencijalnog ishoda koji bi se realizirao da je vjerovao liječniku. Isplata pacijenta je tada $1-f_{p}(1-0)=1-f_{p}$, gdje je $f_{p} \in\langle 0,1]$ koeficijent frustracije pacijenta.

Osim čistih strategija liječnik i pacijent na raspolaganju imaju i mješovite strategije. Mješovite strategije opisuju učestalost ili vjerojatnost odabira pojedinih čistih strategija. Neka je $l \in[0,1]$ vjerojatnost da je liječnik izabrao strategiju L i $v \in[0,1]$ vjerojatnost da je pacijent izabrao strategiju V. Tada je $1-l \in[0,1]$ vjerojatnost da je liječnik izabrao strategiju NL i $1-v \in[0,1]$ vjerojatnost da je pacijent izabrao strategiju NV. Ukupna očekivana korisnost liječnika je

$$
T E u_{d}=\left[\left(1+f_{d}\right) v-f_{d}\right] l \cdot
$$

Za dano $v$. liječnik maksimizira očekivanu korisnost po $l$,

$$
\max _{l \in[0,1]} T E u_{d}=\left[\left(1+f_{d}\right) v-f_{d}\right] l
$$

iz čega se na osnovi predznaka koeficijenta smjera linearne funkcije cilja dobiva korespondencija reakcije liječnika

$$
l(v)= \begin{cases}0, & v<v^{*} \\ {[0,1],} & v=v^{*} \\ 1, & v>v^{*}\end{cases}
$$

gdje je $v^{*}=\frac{f_{d}}{1+f_{d}}$.

Ukupna očekivana korisnost pacijenta je

$T E u_{p}=1-f_{p}-\left(1+r-f_{p}\right) l+\left[\left(2+2 r-f_{p}\right) l-\left(1+r-f_{p}\right)\right] v$

Za dano $l$ pacijent maksimizira očekivanu korisnost po $v$,

$\max _{D \in[0.1]} T E u_{p}=1-f_{p}-\left(1+r-f_{p}\right) l+\left[\left(2+2 r-f_{p}\right) l-\left(1+r-f_{p}\right)\right] v$

iz čega se na osnovi predznaka koeficijenta smjera linearne funkcije cilja dobiva korespondencija reakcije pacijenta

$$
v(l)= \begin{cases}0, & l<l^{*} \\ {[0,1],} & l=l^{*} \\ 1, & l>l^{*}\end{cases}
$$

gdje je $l^{*}=\frac{1+r-f_{p}}{2+2 r-f_{p}}$.

Odgovarajuće krivulje reakcije liječnika i pacijenta prikazane su na Slici 2.

Na presjeku krivulja reakcije liječnika i pacijenta nalaze se tri Nashove ravnoteže. Dvije su u prostoru čistih strategija $(0,0)$ i $(1,1)$ i jedna je u prostoru

Slika 2. Krivulje reakcije liječnika i pacijenta i Nashove ravnoteže

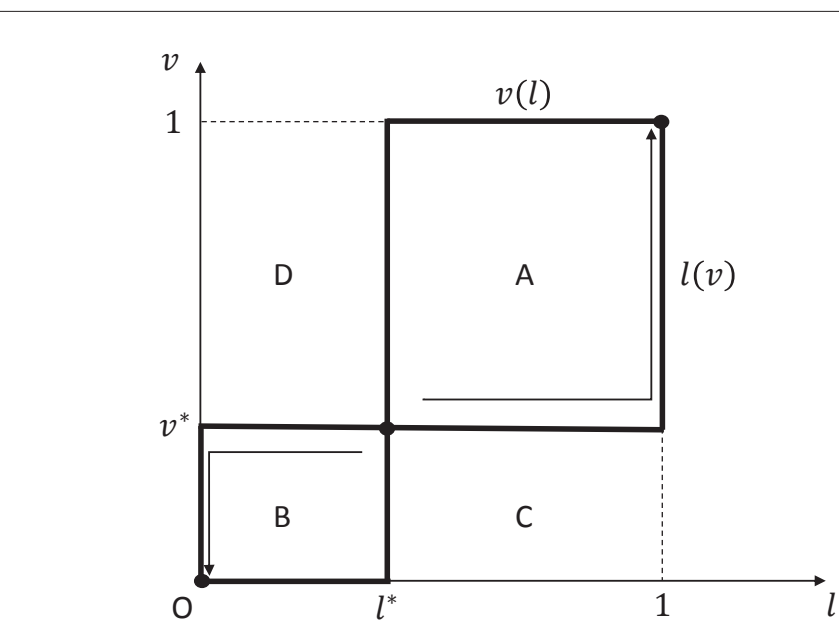

Izvor: izrada autora. 
mješovitih strategija $\left(l^{*}, v^{*}\right)$. Ovdje $(l, v)$ znači da liječnik $s$ vjerojatnošću $l$ bira strategiju $L$ i s vjerojatnošću $1-l$ bira strategiju NL, dok pacijent $s$ vjerojatnošću $v$ bira strategiju $\mathrm{V}$ i s vjerojatnošću $1-v$ bira strategiju NV. Postavlja se pitanje koja se od te tri Nashove ravnoteže može interpretirati kao rezultat igre. Može se primijetiti da krivulje reakcije liječnika i pacijenta relevantno područje vjerojatnosti dijele na četiri dijela koja su označena sa A, B, C i D. Vidljivo je da je ravnoteža $\left(l^{*}, v^{*}\right)$ nestabilna u sljedećem smislu. Mali pomak prema desno i/ili gore u područje A nakon reakcija liječnika i pacijenta vodi u stabilnu ravnotežu $(1,1)$ koja predstavlja društveno poželjan ishod. Taj ishod je društveno poželjan jer liječnik sigurno propisuje terapiju pacijentu koji mu u potpunosti vjeruje i liječi se. Slično mali pomak prema lijevo i/ili dolje u područje B nakon reakcija liječnika i pacijenta vodi u stabilnu ravnotežu $(0,0)$. Taj ishod nije društveno poželjan jer liječnik ne obavlja svoj posao, a pacijent potrebnu zdravstvenu skrb dobiva od drugog liječnika. Njegovu frustraciju pojačavaju troškovi koje ima zbog potrebe za privatnom zdravstvenom zaštitom. Ekonomski gubici se očituju u financiranju zdravstvene zaštite koja se ne dobiva i dodatnim troškovima privatne zdravstvene zaštite. Pomak prema desno i dolje u područje C ili pomak prema lijevo i gore može voditi prema bilo kojoj od dvije stabilne ravnoteže ovisno o tome reagira li prvi liječnik ili pacijent. Ovu neodređenost može riješiti složeniji pristup koji se zasniva na evolucijskoj teoriji igara. Njezina primjena se zasniva na pretpostavci postupne prilagodbe gdje liječnik i pacijent učestalije biraju strategije koje im daju veću očekivanu korisnost od ukupne ili prosječne očekivane korisnost. Pojam mješovite strategije se može interpretirati na još jedan način. U toj interpretaciji vjerojatnost izbora neke čiste strategije predstavlja udio jedinki u populaciji koje uvijek izabiru tu čistu strategiju. Može se reći da raste relativna frekvencija jedinki koje svojim obilježjima izabiru strategiju koja im daje veću korisnost od prosječne i da opada relativna frekvencija jedinki koje svojim obilježjima izabiru strategiju koja im daje manju korisnost od prosječne. Ova misao u skladu je sa osnovnom idejom evolucije prema kojoj s vremenom opstaju natprosječni $\mathrm{i}$ oni koji se mogu prilagoditi i izumiru ispodprosječni i neprilagodljivi. Promjene u populaciji liječnika i populaciji pacijenata opisuje replikatorna dinamika. Prema replikatornoj dinamici relativna stopa promjene udjela jedinki koje izabiru neku strategiju jednaka je razlici očekivane korisnosti te strategije i ukupne očekivane korisnosti. Očekivana korisnost liječnika koji izabire strategiju L je

Slika 3. Izokline i predznak stope promjene relativne frekvencije liječnika koji žele liječiti i stope promjene relativne frekvencije pacijenata koji vjeruju liječnicima

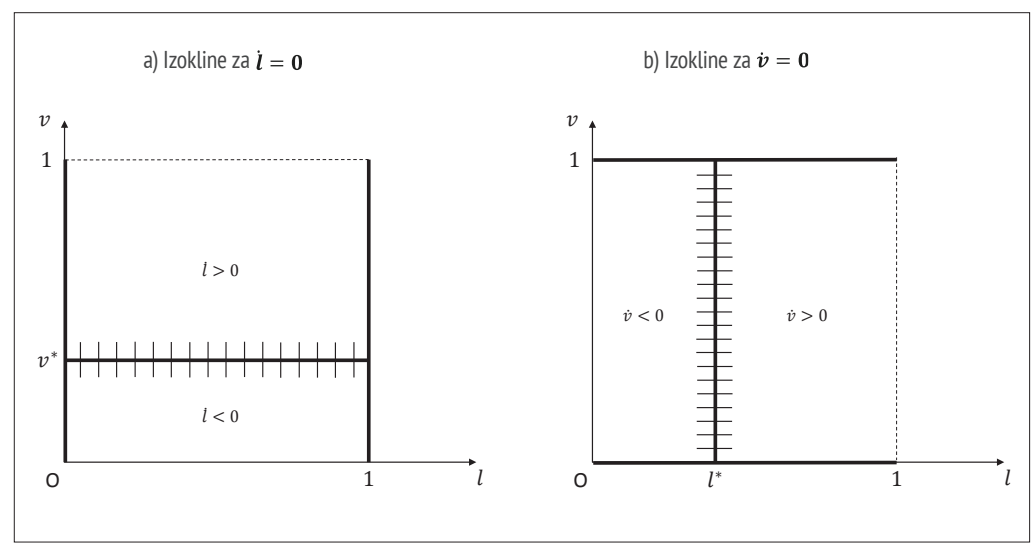

Izvor: izrada autora. 
Vrankić, I.

Mikroekonomska analiza utjecaja emocija liječnika i pacijenata na ishode zdravstvene zaštite

$$
E u_{d}(L)=\left(1+f_{d}\right) v-f_{d}
$$

a očekivana korisnost pacijenta koji izabire strategiju V je

$$
E u_{p}(V)=(1+r) l-r .
$$

Prema tome razlika očekivane korisnosti liječnika koji izabire strategiju L i ukupne očekivane korisnosti je

$$
E u_{d}(L)-T E u_{d}=(1-l)\left[\left(1+f_{d}\right) v-f_{d}\right]
$$

a razlika očekivane korisnosti pacijenta koji izabire strategiju V i ukupne očekivane korisnost je

$E u_{p}(V)-T E u_{p}=(1-v)\left[\left(2+2 r-f_{p}\right) l-\left(1+r-f_{p}\right)\right]$

Primjenom replikatorne dinamike dobiva se sustav diferencijalnih jednadžbi

$\underline{i=F_{1}(l, v)=l(1-l)\left[\left(1+f_{d}\right) v-f_{d}\right]}$

$$
\dot{v}=F_{2}(l, v)=v(1-v)\left[\left(2+2 r-f_{p}\right) l-\left(1+r-f_{p}\right)\right]
$$

Jednadžbe za komplementarne vjerojatnosti ne treba promatrati. Na Slici 3. prikazane su izokline i predznak stope promjene relativne frekvencije liječnika koji žele liječiti i stope promjene relativne frekvencije pacijenata koji vjeruju liječnicima.

Na presjeku tih izoklina nalazi se pet stacionarnih točaka (Slika 4.). To su $(0,0),(0,1),(1,0),(1,1)$ i $\left(l^{*}, v^{*}\right)$. Tri od njih opisuju Nashovu ravnotežu: $(0,0)$ i $(1,1)$ i $\left(l^{*}, v^{*}\right)$. Analiza stabilnosti stacionarnih točaka zasniva se na teoremu 0 stabilnosti nelinearnih sustava (Simon i Blume, 1994, str. 687). Za primjenu tog teorema potrebno je naći Jacobijevu matricu i izračunati svojstvene vrijednosti za svaku stacionarnu točku. Jacobijeva matrica vektorske funkcije $F(l, v)=\left(F_{1}(l, v), F_{2}(l, v)\right)$ je

$$
\begin{gathered}
J F(l, v)=\left[\begin{array}{cc}
\frac{\partial F_{1}}{\partial l} & \frac{\partial F_{1}}{\partial v} \\
\frac{\partial F_{2}}{\partial l} & \frac{\partial F_{2}}{\partial v}
\end{array}\right], \\
J F(l, v)=\left[\begin{array}{cc}
(1-2 l)\left[\left(1+f_{d}\right) v-f_{d}\right] & l(1-l)\left(1+f_{d}\right) \\
v(1-v)\left(2+2 r-f_{p}\right) & (1-2 v)\left[\left(2+2 r-f_{p}\right) l-\left(1+r-f_{p}\right)\right]
\end{array}\right] .
\end{gathered}
$$

Za svaku od navedenih stacionarnih točaka Jacobijeva matrica i svojstvene vrijednosti su:

$$
\begin{gathered}
J F(0,0)=\left[\begin{array}{cc}
-f_{d} & 0 \\
0 & -\left(1+r-f_{p}\right)
\end{array}\right], \lambda_{1}=-f_{d}<0, \lambda_{2}=-\left(1+r-f_{p}\right)<0, \\
J F(0,1)=\left[\begin{array}{cc}
1 & 0 \\
0 & 1+r-f_{p}
\end{array}\right], \lambda_{1}=1>0, \lambda_{2}=1+r-f_{p}>0, \\
J F(1,0)=\left[\begin{array}{cc}
f_{d} & 0 \\
0 & 1+r
\end{array}\right], \lambda_{1}=f_{d}>0, \lambda_{2}=1+r>0, \\
J F(1,1)=\left[\begin{array}{cc}
-1 & 0 \\
0 & -(1+r)
\end{array}\right], \lambda_{1}=-1<0, \lambda_{2}=-(1+r)<0 \mathrm{i} \\
J F\left(l^{*}, v^{*}\right)=\left[\begin{array}{cc}
0 & \frac{\left(1+r-f_{p}\right)(1+r)\left(1+f_{d}\right)}{\left(2+2 r-f_{p}\right)^{2}} \\
\frac{f_{d}\left(2+2 r-f_{p}\right)}{\left(1+f_{d}\right)^{2}} & 0
\end{array}\right], \lambda_{1,2}= \pm \sqrt{\frac{f_{d}\left(1+r-f_{p}\right)(1+r)}{\left(1+f_{d}\right)\left(2+2 r-f_{p}\right)}}, \lambda_{1}<0, \lambda_{2}>0 .
\end{gathered}
$$


Stacionarne točke $(0,0)$ i $(1,1)$ su asimptotski stabilne stacionarne točke ili točke privlačenja jer su obje pripadajuće svojstvene vrijednosti negativne.Za stacionarne točke $(0,1) i(1,0)$ su obje pripadajuće svojstvene vrijednosti pozitivne i to su nestabilne stacionarne točke odbijanja. Stacionarna točka $\left(l^{*}, v^{*}\right)$ ima jednu negativnu i jednu pozitivnu svojstvenu vrijednost pa je to nestabilna stacionarna točka. S obzirom na analizu stabilnosti i predznake stope promjene relativne frekvencije liječnika koji žele liječiti i stope promjene relativne frekvencije pacijenata koji vjeruju liječnicima može se konstruirati vektorsko polje i fazni dijagram koji prikazuje promjenu udjela liječnika koji žele liječiti i udjela pacijenata koji vjeruju liječnicima (Slika 4.)

U skladu s prethodnom analizom vidi se da se od tri Nashove ravnoteže dugoročnim rezultatom igre mogu smatrati asimptotski stabilne stacionarne točke ili točke privlačenja $(0,0)$ i $(1,1)$. Sam rezultat ovisi o početnoj točki ili početnom udjelu liječnika koji žele liječiti u populaciji liječnika i početnom udjelu pacijenata koji vjeruju liječnicima u populaciji pacijenata. Na Slici 4.b orbite između stacionarnih točaka $(0,1)$ i $\left(l^{*}, v^{*}\right)$, te $\overline{(1,0)}$ i $\left(l^{*}, v^{*}\right)$ dijele relevantni prostor na dva dijela. Nema više neodređenosti u rezultatu igre. Ako je početno stanje ispod tih dviju orbita dugoročni rezultat jest populacija liječnika koji ne žele liječiti pacijente i populacija pacijenata koji ne vjeruju liječnicima. Ovaj ishod je društveno nepoželjan jer u tom slučaju zdravstvena zaštita koja se financira iz sredstava pacijenata ne funkcionira. Osim toga potrebnu zdravstvenu zaštitu pacijenti tada dobivaju privatno što izaziva osjećaj frustracije i povećava troškove pacijenata. Ako je početno stanje iznad tih dviju orbita dugoročni rezultat jest populacija liječnika koji liječe pacijente i populacija pacijenata koji vjeruju liječnicima. Ovaj ishod je društveno poželjan i postavlja se pitanje kojim mjerama se može ostvariti. Dugoročno su poželjne mjere koje povećavaju područje privlačenja prema točki $(1,1)$, odnosno nestabilnu ravnotežu $\left(l^{*}, v^{*}\right)$ pomiču prema dolje i/ili lijevo. Ovdje je komparativno statička analiza jednostavna jer je

$\frac{\partial l^{*}}{\partial r}=\frac{f_{p}}{\left(2+2 r-f_{p}\right)^{2}}>0, \frac{\partial l^{*}}{\partial f_{p}}=-\frac{1+r}{\left(2+2 r-f_{p}\right)^{2}}<C_{\mathrm{i}} \frac{d v^{*}}{d f_{d}}=\frac{1}{\left(1+f_{d}\right)^{2}}>0$.

Prema tome $l^{*}$ je rastuća funkcija u $r$ i opadajuća u $\overline{f_{p}}$, a $v^{*}$ je rastuća funkcija u $f_{d}$. Prirodno je očekivati da je koeficijent žaljenja pacijenata veći u slučaju značajnijih zdravstvenih tegoba. Ovdje je važno naglasiti da se interpretacija izvedenih rezultata u ovom radu razlikuje od uobičajenih interpretacija koje ne uzimaju u obzir sposobnost prilagodbe u vremenu. Tako se u literaturi obično navodi propozicija 0 irelevantnosti isplata prema kojoj se u svom radu Hirshleifer (2001.) kritički odnosi. Prema toj propoziciji pod određenim uvjetima promjene $u$ isplatama jednog igrača utječu samo na strategiju drugog igrača u Nashovoj ravnoteži s mješovitim strategijama. Ta se propozicija ovdje

Slika 4. Vektorsko polje i fazni dijagram

a) Vektorsko polje

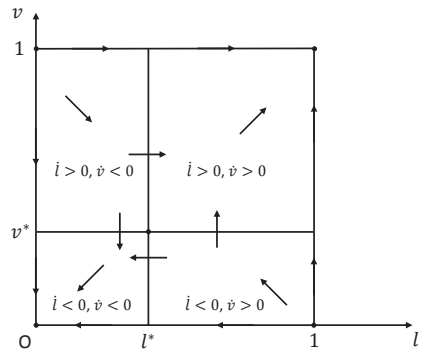

b) Fazni dijagram

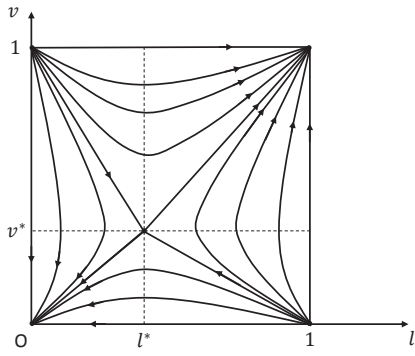

Vrankić, I.

Mikroekonomska analiza utjecaja emocija liječnika i pacijenata na ishode zdravstvene zaštite

Izvor: izrada autora. 
Vrankić, I.

Mikroekonomska analiza utjecaja emocija liječnika i pacijenata na ishode zdravstvene zaštite očituje u činjenici da u mješovitoj Nashovoj ravnoteži $\left(l^{*}, v^{*}\right)$ optimalno ponašanje liječnika ne ovisi o koeficijentu frustracije liječnika i optimalno ponašanje pacijenta ne ovisi o koeficijentu žaljenja i koeficijentu frustracije pacijenta. Izravna primjena te propozicije bi navela na zaključak da povećanje koeficijenta žaljenja pacijenta u slučaju značajnijīh zdravstvenih tegoba ne utječe na ponašanje pacijenta jer se $v^{*}$ ne mijenja. Ta promjena utječe samo na ponašanje liječnika koji učestalije žele liječiti pacijente jer se $l^{*}$ povećava. Formalno to vrijedi za mješovitu Nashovu ravnotežu $\left(l^{*}, v^{*}\right)$ koja se pomiče udesno. Ova interpretacija ne propituje način na koji se uspostavlja Nashova ravnoteža, kao ni njezinu održivost u vremenu. Fazni dijagram na Slici 4. pokazuje da mala perturbacija u mješovitoj Nashovoj ravnoteži $\left(l^{*}, v^{*}\right)$ uzrokuje značajne promjene $u$ ponašanju liječnika i pacijenata $u$ vremenu, pa se može reći da ta Nashova ravnoteža dugoročno nije održiva. Pomicanjem te nestabilne Nashove ravnoteže $\left(l^{*}, v^{*}\right)$ prema desno smanjuje se područje privlačenja prema stabilnoj Nashovoj ravnoteži $(1,1)$ i povećava područje privlačenja prema stabilnoj Nashovoj ravnoteži $(0,0)$. Ako je stanje sustava u području promjene onda se ponašanje liječnika i pacijenata dugoročno drastično mijenja i dugoročni učinak povećanja koeficijenta žaljenja pacijenata može biti da se umjesto društveno poželjne populacije liječnika koji žele liječiti i pacijenata koji vjeruju liječnicima dobije društveno nepoželjna populacija liječnika koji ne žele liječiti i pacijenata koji ne vjeruju liječnicima.

Ako se poveća koeficijent frustracije pacijenata jer je mišljenje drugog liječnika teže dostupno ili su troškovi privatnog liječenja značajniji onda se mješovita Nashova ravnoteža pomiče prema lijevo i područje privlačenja prema društveno poželjnom stanju zdravstvenog sustava se širi. Premda bi se ovaj učinak mogao postići skupljim privatnim liječenjem ova mjera je kontroverzna jer povećava troškove pacijenata. Kada bi se umanjila frustracija liječnika koji žele liječiti pacijente koji ne uzimaju terapiju mješovita Nashova ravnoteža bi se pomakla prema dolje i područje privlačenja prema društveno poželjnom stanju zdravstvenog sustava bi se povećalo.

\subsection{Model s frustracijom, žaljenjem i krivnjom}

S obzirom na poteškoće u implementaciji kompenzacije liječnicima zbog frustracije koju osjećaju kada pacijenti ne uzimaju preporučenu terapiju postavlja se pitanje može li se društveno poželjno stanje zdravstvenog sustava dugoročno ostvariti utjecajem na emocije liječnika koji ne posvećuju vrijeme pacijentima, ne liječe in i ne propisuju potrebnu terapiju. $U$ ovom poglavlju se model proširuje varijablom koja opisuje krivnju tih liječnika. Pretpostavlja se da se isplate liječnika koji ne propisuju terapiju umanjuju za koeficijent krivnje $-g \in[0,1]$ i matrica isplata prikaza prikazana je na Slici 5.

Kada je $g=0$ dobiju se rezultati iz prethodnog poglavlja. Za pozitivne $g$ ukupna očekivana korisnost liječnika je

$T E u_{d}=\left[\left(1+f_{d}\right) v-f_{d}+g\right] l-g$.

Za dano $v$ liječnik maksimizira očekivanu korisnost po $l$,

$\max _{l \in[0,1]} T E u_{d}=\left[\left(1+f_{d}\right) v-f_{d}+g\right] l-g$

iz čega se na osnovi predznaka koeficijenta smjera linearne funkcije cilja dobiva krivulja reakcije liječnika (Slika 6.) pri čemu se razlikuju tri slučaja ¡ $v^{* *}=\frac{f_{d}-g}{1+f d^{*}}$.

Slika 5. Matrica isplata koje uključuju krivnju liječnika

$$
\begin{array}{ccc} 
& \mathrm{V} & \mathrm{NV} \\
\text { Liječnik } & \mathrm{L} \\
\mathrm{NL}
\end{array}\left[\begin{array}{cc}
1,1 & -f_{d},-r \\
-g,-r & -g, 1-f_{p}
\end{array}\right]
$$

Izvor: izrada autora. 

a) $g<f_{d}$
b) $\boldsymbol{g}=\boldsymbol{f}_{\boldsymbol{d}}$
c) $\boldsymbol{g}>\boldsymbol{f}_{\boldsymbol{d}}$

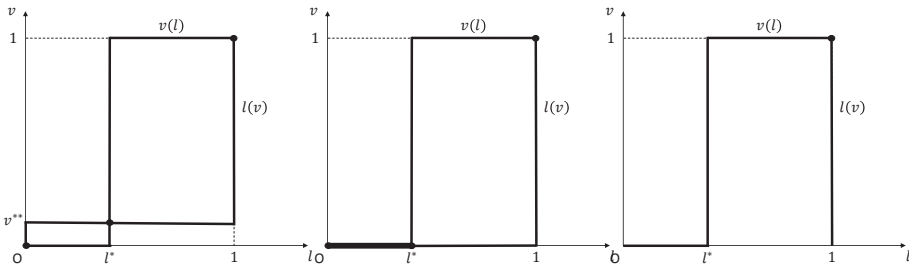

Vrankić, I.

Mikroekonomska analiza utjecaja emocija liječnika i pacijenata na ishode zdravstvene zaštite

Izvor: izrada autora.

Krivulja reakcije pacijenta se ne mijenja. Ako je $\overline{g<f_{d}}$ onda su Nashove ravnoteže $\overline{(0,0)}, \overline{\left(l^{*}, v^{* *}\right)}$ i $(1,1)$.

Ako je $g=f_{d}$ onda su Nashove ravnoteže prikazane segmentom $\left\{(l, 0): l \in\left[0, l^{*}\right\rceil\right]$ i točkom $(1,1)$.

Ako je $g>f_{d}$ onda je Nashova ravnoteža samo $(1,1)$.

Razlika očekivane korisnosti liječnika koji izabire strategiju L i ukupne očekivane korisnosti je sada

$$
J F(l, v)=\left[\begin{array}{c}
(1-2 l)\left[\left(1+f_{d}\right) v-f_{d}+g\right] \\
v(1-v)\left(2+2 r-f_{p}\right)
\end{array}\right.
$$

U nastavku se svaki od tri slučaja posebno analizira.

Ako je $g<f_{d}$ onda Slika 7. prikazuje vektorsko polje i fazni dijagram. Na presjeku izoklina nalazi se pet stacionarnih točaka $(0,0),(0,1),(1,0),(1,1)$
$E u_{d}(L)-T E u_{d}=(1-l)\left[\left(1+f_{d}\right) v-f_{d}+g\right]$, Primjenom replikatorne dinamike dobiva se sustav diferencijalnih jednadžbi u kojem se promijenila samo prva jednadžba

$$
\begin{gathered}
i=F_{1}(l, v)=l(1-l)\left[\left(1+f_{d}\right) v-f_{d}+g\right] \\
\dot{v}=F_{2}(l, v)=v(1-v)\left[\left(2+2 r-f_{p}\right) l-\left(1+r-f_{p}\right)\right] .
\end{gathered}
$$

Jacobijeva matrica je

$l(1-l)\left(1+f_{d}\right)$
$\left.(1-2 v)\left[\left(2+2 r-f_{p}\right) l-\left(1+r-f_{p}\right)\right]\right]$

i $(0,0)$ od kojih tri opisuju Nashovu ravnotežu $(0,0)$, $(1,1) \mathrm{i}\left(l^{*}, v^{* *}\right)$. Za svaku od navedenih stacionarnih točaka Jacobijeva matrica i svojstvene vrijednosti su:

$$
\begin{gathered}
J F(0,0)=\left[\begin{array}{cc}
-f_{d}+g & 0 \\
0 & -\left(1+r-f_{p}\right)
\end{array}\right], \lambda_{1}=-f_{d}+g<0, \lambda_{2}=-\left(1+r-f_{p}\right)<0, \\
J F(0,1)=\left[\begin{array}{cc}
1+g & 0 \\
0 & 1+r-f_{p}
\end{array}\right], \lambda_{1}=1+g>0, \lambda_{2}=1+r-f_{p}>0, \\
J F(1,0)=\left[\begin{array}{cc}
f_{d}-g & 0 \\
0 & 1+r
\end{array}\right], \lambda_{1}=f_{d}-g>0, \lambda_{2}=1+r>0, \\
J F(1,1)=\left[\begin{array}{cc}
-(1+g) & 0 \\
0 & -(1+r)
\end{array}\right], \lambda_{1}=-(1+g)<0, \lambda_{2}=-(1+r)<0 \mathrm{i} \\
0
\end{gathered}
$$


Vrankić, I.

Mikroekonomska analiza utjecaja emocija liječnika i pacijenata na ishode zdravstvene zaštite

Slika 7. Vektorsko polje i fazni dijagram u slučaju $\boldsymbol{g}<\boldsymbol{f}_{\boldsymbol{d}}$

a) Vektorsko polje

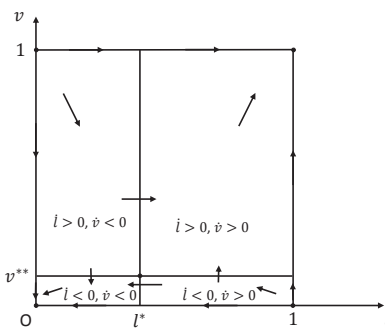

b) Fazni dijagram

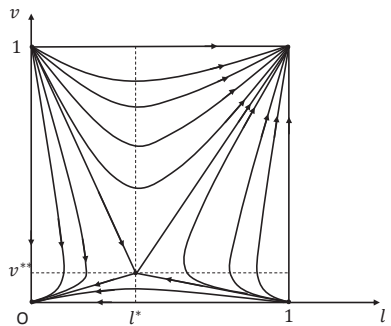

Izvor: izrada autora.

Analiza je slična analizi iz prethodnog poglavlja zbog analogije predznaka stope promjene relativne frekvencije liječnika koji žele liječiti i stope promjene relativne frekvencije pacijenata koji vjeruju liječnicima i predznaka svojstvenih vrijednosti za odgovarajuće stacionarne točke.

Može se primijetiti da je osjećaj krivnje liječnika koji ne žele liječiti pacijente povećao područje privlačenja prema društveno poželjnom stanju zdravstvenog sustava jer je $v^{* *}<v^{*} \mathrm{i}$ da je taj učinak veći što je osjećaj krivnje izraženiji.

Ako je $\overline{g=f_{d}}$ onda Slika 8. prikazuje vektorsko polje i fazni dijagram. Na presjeku izoklina nalaze se stacionarne točke $(0,1),(1,1)$ i točke na segmentu $\overline{\{(l, 0): l \in[0,1]\}}$ od kojih Nashovu ravnotežu opisuju točka $(1,1)$ i točke na segmentu $\left\{(l, 0): l \in\left[0, l^{*}\right]\right\}$ Z Za svaku od navedenih stacionarnih točaka Jacobijeva matrica i svojstvene vrijednosti su:

$$
\begin{gathered}
J F(0,1)=\left[\begin{array}{cc}
1+g & 0 \\
0 & 1+r-f_{p}
\end{array}\right], \lambda_{1}=1+g>0, \lambda_{2}=1+r-f_{p}>0 \\
J F(1,1)=\left[\begin{array}{cc}
-1+g) & 0 \\
0 & -(1+r)
\end{array}\right], \lambda_{1}=-(1+g)<0, \lambda_{2}=-(1+r)<0 \mathrm{i} \\
J F(l, 0)=\left[\begin{array}{cc}
0 & l(1-l)\left(1+f_{d}\right) \\
0 & \left(2+2 r-f_{p}\right) l-\left(1+r-f_{p}\right)
\end{array}\right] \\
\lambda_{1}=0, \lambda_{2}=\left(2+2 r-f_{p}\right) l-\left(1+r-f_{p}\right) .
\end{gathered}
$$

Stacionarna točka $(1,1)$ je asimptotski stabilna stacionarna točka ili točka privlačenja jer su obje pripadajuće svojstvene vrijednosti negativne. Za stacionarnu točku $\overline{(0,1)}$ su obje pripadajuće svojstvene vrijednosti pozitivne i to je nestabilna stacionarna točka odbijanja. Za stacionarne točke iz intervala $\overline{\left\{(l, 0): l \in\left[0, l^{*}\right\rangle\right\}}$ je $\overline{\lambda_{2}<0}$ i stabilnost tih stacionarnih točaka se ne može odrediti na osnovi predznaka svojstvenih vrijednosti. Za stacionarnu točku $\left(l^{*}, 0\right)$ je $\lambda_{2}=0$ i ponovno se stabilnost ne može odrediti na osnovi predznaka svojstvenih vrijednosti. Za stacionarne točke iz intervala $\overline{\left\{(l, 0): l \in\left\langle l^{*}, 1\right]\right\}}$ je $\overline{\lambda_{2}>0}$ i to su nestabilne stacionarne točke jer ime je jedna pripadajuća svojstvenu vrijednost pozitivna. S obzirom na neodređenost stabilnosti stacionarnih točaka iz segmenta $\left\{(l, 0): l \in\left[0, l^{*}\right]\right\}$ fazni dijagram se ne može konstruirati kao u prethodnim slučajevima. 
Zbog toga se ovdje primjenjuje metoda prvog integrala. S obzirom da je općenito

$\frac{\ddot{v}}{i}=\frac{v(1-v)(c l-d)}{l(1-l)(a v-b)}=\frac{d v}{d l}$,

gdje je $a=1+f_{d}, b=f_{d}-g, c=2+2 r-f_{p}$ i

$\overline{d=1+r-f_{p}}$,

metodom separiranja varijabli dobije se

$\left(-\frac{d}{l}+\frac{c-d}{1-l}\right) d l=\left(-\frac{b}{v}+\frac{a-b}{1-v}\right) d v$

$-d \ln l-(c-d) \ln (1-l)+k=-b \ln v-(a-b) \ln (1-v)$

$k=\ln \frac{l^{d}(1-l)^{c-d}}{v^{b}(1-v)^{a-b}}$,

i rezultat vrijedi i za $b=0$.

Prematome prvi integralje $G(l, v)=\ln \frac{l^{d}(1-l)^{c-d}}{v^{b}(1-v)^{a-b}}$

i orbite su sadržane u njegovim nivo linijama. $\mathrm{Za}$ $g=f_{a}$ je $b=0$ i $G(l, v)=\ln \frac{l^{d}(1-l)^{c-d}}{(1-v)^{a-b}}$ pa su nivo linije oblika

$v=1-k^{*} l^{\frac{d}{a}}(1-l)^{\frac{c-d}{a}}, k^{*}>0$.

Sobzirom da je

$\overline{\frac{d v}{d l}=-\frac{k^{*}}{a} l^{\frac{d}{a}-1}(1-l)^{\frac{c-d}{a}-1}(d-c l)}$

vidi se da $v$ na intervalu $\overline{\left[0, l^{*}\right]}$ opada, a na intervalu $\left[l^{*}, 1\right]$ raste. Minimum funkcije $v$. na intervalu $[0,1]$ može poprimiti pozitivne, ali i negativne vrijednosti za dovoljno veliki $k^{*}$, pa je važno naglasiti da se mapa nivo linija crta samo u relevantnom području i da su orbite kao i stacionarne točke dijelovi nivo linija prvog integrala. U skladu s navedenim dobije se fazni dijagram na Slici 8.

Iz faznog dijagrama se vidi da su stacionarne točke iz intervala $\left\{(l, 0): l \in\left[0, l^{*}\right\rangle\right\}$ neutralno stabilne jer mala perturbacija ne uzrokuje značajnu promjenu dugoročnog ponašanja liječnika i pacijenata. Ako je početno stanje zdravstvenog sustava ispod orbite između stacionarnih točaka $(0,1)$ i $\left(l^{*}, 0\right)$ dugoročni rezultat je populacija liječnika koji samo dijelom žele liječiti pacijente i populacija pacijenata koja ne vjeruje liječnicima.Udio liječnika koji žele liječiti pacijente je između 0 i $l^{*}$. Kada je taj udio pozitivan ova situacija je društveno izrazito nepovoljna, nepovoljnija od ishoda koji odgovara populaciji liječnika koji ne žele liječiti pacijente i populacija pacijenata koji ne vjeruju liječnicima. Razlog je što tada dio pacijenata ne uzima terapiju koju im liječnici koji žele liječiti propisuju i ne liječi se. Ako je početno stanje zdravstvenog sustava desno od orbite između stacionarnih točaka $(0,1)$ $\overline{\left(l^{*}, 0\right)}$ dugoročni rezultat je populacija liječnika koji žele liječiti pacijente i populacija pacijenata koja vjeruje liječnicima. Taj ishod je društveno poželjan. Ovisno 0 početnim uvjetima rezultatom igre mogu se smatrati Nashove ravnoteže na intervalu $\left\{(l, 0): l \in\left[0, l^{*}\right\rangle\right\}$ i točka $(1,1)$. Veličina područja privlačenja prema društveno poželjnom stanju se poveća kada se koeficijent žaljenja pacijenata smanji ili koeficijent frustracije pacijenata poveća.

Ako je $g>f_{d}$ onda Slika 9. prikazuje vektorsko
Vrankić, I.

Mikroekonomska analiza utjecaja emocija liječnika i pacijenata na ishode zdravstvene zaštite

Slika 8. Vektorsko polje i fazni dijagram u slučaju $\boldsymbol{g}=\boldsymbol{f}_{d}$

a) Vektorsko polje

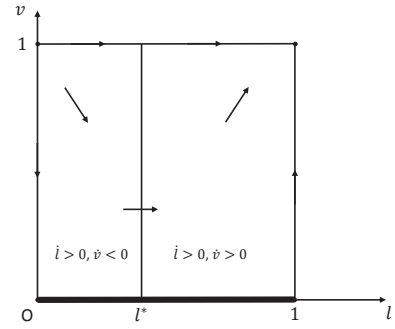

b) Fazni dijagram

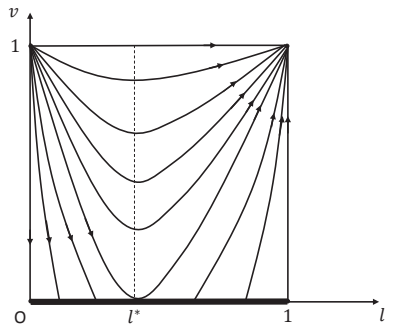

Izvor: izrada autora. 
Vrankić, I.

Mikroekonomska analiza utjecaja emocija liječnika i pacijenata na ishode zdravstvene zaštite polje i fazni dijagram. Na presjeku izoklina nalaze se četiri stacionarne točke $(0,0),(0,1),(1,0)$ i $(1,1)$ od kojih jedna opisuje Nashovu ravnotežu $(0,0)$. Za svaku od navedenih stacionarnih točaka Jacobijeva matrica i svojstvene vrijednosti su:

$$
\begin{gathered}
J F(0,0)=\left[\begin{array}{cc}
-f_{d}+g & 0 \\
0 & -\left(1+r-f_{p}\right)
\end{array}\right], \lambda_{1}=-f_{d}+g>0, \lambda_{2}=-\left(1+r-f_{p}\right)<0, \\
J F(0,1)=\left[\begin{array}{cc}
1+g & 0 \\
0 & 1+r-f_{p}
\end{array}\right], \lambda_{1}=1+g>0, \lambda_{2}=1+r-f_{p}>0 \\
J F(1,0)=\left[\begin{array}{cc}
f_{d}-g & 0 \\
0 & 1+r
\end{array}\right], \lambda_{1}=f_{d}-g<0, \lambda_{2}=1+r>0 \mathrm{i} \\
J F(1,1)=\left[\begin{array}{cc}
-(1+g) & 0 \\
0 & -(1+r)
\end{array}\right], \lambda_{1}=-(1+g)<0, \lambda_{2}=-(1+r)<0 .
\end{gathered}
$$

Stacionarna točka $(1,1)$ je asimptotski stabilna stacionarna točka ili točka privlačenja jer su obje pripadajuće svojstvene vrijednosti negativne. Za stacionarnu točku $(0,1)$ su obje pripadajuće svojstvene vrijednosti pozitivne i to je nestabilna stacionarna točka odbijanja. Stacionarne točke $(0,0)$ i $(1,0)$ imaju jednu negativnu i jednu pozitivnu pripadajuću svojstvenu vrijednost pa su to nestabilne stacionarna točka. S obzirom na analizu stabilnosti i predznake stope promjene relativne frekvencije liječnika koji žele liječiti i stope promjene relativne frekvencije pacijenata koji vjeruju liječnicima može se konstruirati vektorsko polje i fazni dijagram koji prikazuje promjenu udjela liječnika koji žele liječiti i udjela pacijenata koji vjeruju liječnicima (Slika 9.).

I z faznog dijagrama se vidi da jedinstvena Nashova ravnoteža predstavlja rezultat igre. Sve orbite vode prema dugoročno poželjnom stanju populacije liječnika koji žele liječiti i populacije pacijenata koji vjeruju liječnicima uz izuzetak orbita na koordinatnim osima. Ovaj dugoročno poželjan ishod zdravstvene zaštite se postiže kada krivnja liječnika koji ne propisuju terapiju dominira u odnosu na osjećaj frustracije liječnika koji propisuju terapiju koju pacijenti ne uzimaju. Izvedeni rezultat ne

Slika 9. Vektorsko polje i fazni dijagram u slučaju $\boldsymbol{g}>\boldsymbol{f}_{d}$

a) Vektorsko polje

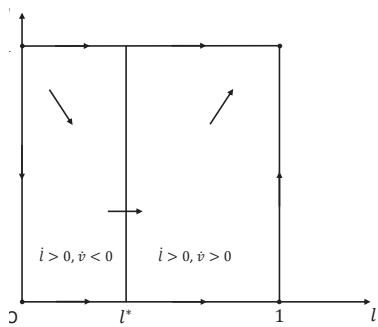

b) Fazni dijagram

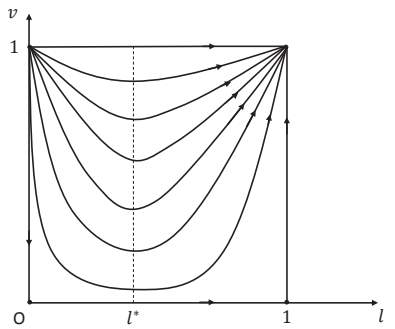

Izvor: izrada autora. 
ovisi o osjećajima žaljenja i frustracije pacijenata. S obzirom da je tada dugoročni ishod zdravstvene zaštite društveno poželjan postavlja se pitanje na koji se praktični način može postići da potencijalna krivnja liječnika bude izraženija od osjećaja frustracije. Jedan smjer jest oplemenjivanje sustava vrijednosti u kojem se u medicini orijentiranoj na pacijenta veća težina daje negativnom osjećaju liječnika koji nastaje kada propusti djelovati nego negativnom osjećaju liječnika kada pacijent propusti djelovati. Drugi smjer je manje sofisticiran i odnosi se na potencijalno penaliziranje liječnika koji ne propisuju terapiju pacijentima.

\section{Zaključak}

Neovisno o modelu financiranja zdravstvenog sustava barem dio financijskih sredstava za zdravstvenu zaštitu izdvajaju njezini korisnici. Zbog toga zdravstvena zaštita predstavlja ne samo zdravstveni nego i ekonomski problem osobito kada značajan broj pacijenata nije zadovoljan dostupnošću zdravstvenih usluga zbog financijskih razloga, geografskog položaja ili predugog čekanja ili smatraju da dobivena zdravstvena usluga nije adekvatna njihovom zdravstvenom stanju. Neučinkoviti zdravstveni sustav može ugroziti fizičko, psihičko i društveno blagostanje pojedinca koji je često prinuđen da primjerenu zdravstvenu skrb realizira kroz sustav privatne zdravstvene zaštite što značajno utječe na ekonomske troškove liječenja. U tom slučaju ekonomski troškovi obuhvaćaju dodatna financijska izdvajanja za zdravstvene usluge, oportunitetne troškove koji nastaju jer pojedinac nije u mogućnosti raditi, troškove prijevoza do zdravstvene ustanove i brojne druge popratne troškove. Pritom pacijent kojemu je ugroženo zdravstveno stanje proživljava brojne negativne emocije koje negativno utječu na njegovo blagostanje. Ovaj rad istražuje kako emocije koje doživljavaju liječnik i pacijent u međusobnoj interakciji utječu na realizaciju prikladne zdravstvene zaštite i dugoročnu učinkovitost zdravstvenog sustava. U simultanoj igru liječnika i pacijenta liječnici odlučuju 0 tome žele li liječiti pacijente, a pacijenti odlučuju o tome hoće li vjerovati liječnicima. Liječnici i pacijent vremenom prilagođavaju svoje ponašanje i učestalije biraju strategije koje im daju veću očekivanu korisnost od prosječne očekivane korisnosti i ovaj se model analizira primjenom alata evolucijske teorije igara i replikatorne dinamike. Promjene ponašanja liječnika i pacijenta opisuje fazni dijagram pri čemu se analiziraju različiti slučajevi i dolazi do odgovora koja se Nashova ravnoteža može smatrati dugoročnim rezultatom igre. U modelu sa frustracijom i žaljenjem liječnici osjećaju frustraciju kada pacijenti ne uzimaju preporučenu terapiju, pacijenti koji se ne liječe osjećaju žaljenje i pacijenti koji zdravstvenu zaštitu ostvaruju privatno osjećaju frustraciju. Društveno poželjno stanje je populacija liječnika koji žele liječiti pacijente i populacija pacijenata koji vjeruju liječnicima. Nasuprot toga je društveno nepoželjno stanje populacije liječnika koji ne žele liječiti pacijente i populacija pacijenata koji ne vjeruju liječnicima. Veličina područja privlačenja prema ovim stanjima ovise o emocijama koje liječnik i pacijent osjećaju u međusobnoj interakciji. Dugoročni učinak povećanja koeficijenta žaljenja pacijenata može biti da se umjesto društveno poželjne populacije liječnika koji žele liječiti i pacijenata koji vjeruju liječnicima dobije društveno nepoželjna populacija liječnika koji ne žele liječiti i pacijenata koji ne vjeruju liječnicima. Ako se poveća koeficijent frustracije pacijenata jer je mišljenje drugog liječnika teže dostupno ili su troškovi privatnog liječenja značajniji onda se područje privlačenja prema društveno poželjnom stanju zdravstvenog sustava širi. Premda se ovaj učinak može postići skupljim privatnim liječenjem ova mjera je kontroverzna jer povećava troškove pacijenata. Područje privlačenja prema društveno poželjnom stanju zdravstvenog sustava se može povećati ako se umanji frustracija liječnika koji žele liječiti pacijente koji ne uzimaju terapiju. U proširenom modelu sa frustracijom, žaljenjem i krivnjom se pretpostavlja da liječnici koji ne žele liječiti pacijente zbog toga osjećaju krivnju i ovaj model je po izvedenim rezultatima bogatiji. Ako je frustracija liječnika dominantna u odnosu na krivnju onda osjećaj krivnje liječnika koji ne žele liječiti pacijente povećava područje privlačenja prema društveno poželjnom stanju zdravstvenog sustava i taj učinak je veći što je osjećaj krivnje izraženiji ili što je osjećaj frustracije liječnika manje izražen. Na veličinu tog područja također utječu emocije pacijenta i povećava ga veća frustracija i manje žaljenje pacijenta. Kada su koeficijent
Vrankić, I.

Mikroekonomska analiza utjecaja emocija liječnika i pacijenata na ishode zdravstvene zaštite 
Vrankić, I.

Mikroekonomska analiza utjecaja emocija liječnika i pacijenata na ishode zdravstvene zaštite krivnje i frustracije liječnika međusobno jednaki skup mogućih dugoročnih rezultata igre se širi i uključuje populaciju liječnika koji samo dijelom žele liječiti pacijente i populaciju pacijenata koji ne vjeruju liječnicima. Ova situacija je društveno izrazito nepovoljna, nepovoljnija od ishoda koji odgovara populaciji liječnika koji ne žele liječiti pacijente i populacija pacijenata koji ne vjeruju liječnicima. Razlog je što tada dio pacijenata ne uzima terapiju koju im liječnici koji žele liječiti propisuju i ne liječi se.Veličina područja privlačenja prema društveno poželjnom stanju se može povećati ako se koeficijent žaljenja pacijenata smanji ili koeficijent frustracije pacijenata poveća. Ako je krivnja liječnika dominantna u odnosu na frustraciju onda sve orbite vode prema dugoročno društveno poželjnom stanju populacije liječnika koji žele liječiti i populacije pacijenata koji vjeruju liječnicima uz izuzetak orbita na koordinatnim osima i rezultat igre ne ovisi o osjećajima žaljenja i frustracije pacijenata. Ovaj dugoročno društveno poželjan rezultat se može ostvariti na dva načina. Jedan način je utjecaj na savjest liječnika tako da se u medicini orijentiranoj na pacijenta i djelovanje veća težina daje negativnom osjećaju liječnika koji nastaje kada propusti djelovati nego negativnom osjećaju liječnika kada pacijent propusti djelovati. Drugi način je manje sofisticiran i odnosi se na potencijalno penaliziranje liječnika koji ne propisuju terapiju pacijentima. S obzirom da širi skup emocija koje doživljavaju liječnik i pacijent u međusobnoj interakciji značajno utječe na moguće ponašanje sustava izvedene rezultate u ovom radu valja sagledati kritički. Buduća istraživanja trebaju biti usmjerena na obuhvatniji spektar emocija koje utječu na ponašanje liječnika i pacijenata kako bi se metodama koje se upotrebljavaju u ovom radu provjerilo u kojoj mjeri mogu utjecati na dugoročnu učinkovitost zdravstvenog sustava.

\section{Literatura}

Barron, E. N. (2013). Game Theory: An Introduction. Hoboken: Wiley.

Caplin, A., \& Leahy, J. (2001). Psychological Expected Utility Theory and Anticipatory Feelings. The Quarterly Journal of Economics, 116(1): 55-79. https://doi.org/10.1162/003355301556347

Djulbegovic, B., Hozo, I., \& Ioannidis J.P.A.(2015).Modern health care as a game theory problem. European Journal of Clinical Investigation, 45(1): 1-12.https://doi.org/10.1111/eci.12380

Gibbons, R. (1992). Game Theory for Applied Economists. Princeton: Princeton University Press.

Glycopantis, D., \& Stavropoulou, C. (2011). The Supply of Information in an Emotional Setting. CESifo Economic Studies, 57(4): 740-762. https://doi.org/10.1093/cesifo/ifr024

Glycopantis,D., \& Stavropoulou,C.(2018). An agency relationship under general conditions of uncertainty: a game theory application to the doctor-patient interaction. Economic Theory Bulletin, 6: 15-28. https://doi.org/10.1007/s40505-017-0120-9

Hirshleifer,J. (2001). The Dark Side of the Force. Cambridge: Cambridge University Press.

Haurie,A., Krawczyk, J. B., \& Zaccour, G. (2012). Games and Dynamic Games. Montréal: HEC Montréal.

Kőszegi, B. (2006). Emotional Agency. The Quarterly Journal of Economics, 121(1): 121-155. https://doi.org/10.1093/qje/121.1.121

Roca,C.P.,Cuesta,J.A., \& Sánchez,A.(2009). Evolutionary game theory:Temporal and spatial effects beyond replicator dynamics. Physics of Life Reviews, 6: 208 - 249. https://doi.org/10.1016/j.plrev.2009.08.001 
Schecter, S., \& Gintis, H. (2016). An Introduction to Classical and Evolutionary Models. Princeton: Princeton University Press.

Simon, C. P., \& Blume, L. (1994). Mathematics for Economists. New York: Norton\&Co.

Smith, J. M. (1982). Evolution and the Theory of Games. Cambridge: Cambridge University Press. 
